DOI: $10.17234 / S R A Z .65 .36$

UDK: 811.135.1'28

Original scientific paper

Received on 21 April 2020

Accepted for publication on 25 November 2020

\title{
Minority languages in the digital age. Daj Nostri and Bayash Romanian on social media
}

\author{
Annemarie Sorescu-Marinković \\ Institute for Balkan Studies, Belgrade, Serbia \\ annemarie.sorescu@bi.sanu.ac.rs
}

\begin{abstract}
The Bayash are a Romanian-speaking ethnic community spread all over the Balkans, generally considered Roma by the majority populations. This paper deals with a specific Bayash diaspora group, Daj Nostri ("our people"), from Austria, Germany and Switzerland, who have recently started using their native variety, Bayash Romanian, for online communication. The focus is on Daj Nostri Facebook group, which gathers more than 9,000 members, and on the way they use Bayash Romanian online (instances of use, frequency, spelling, plurilingual practices, etc.).
\end{abstract}

Key words: Bayash, Romanian, minority languages, Facebook, online communication

\section{The Bayash diaspora}

The Bayash are an ethnic community speaking archaic varieties of Romanian as their mother tongue, but generally considered Roma by the surrounding populations. Originating in the Romanian Danube Principalities, in the last two centuries they have spread all over the Balkans, Eastern and Central Europe (Marushiakova and Popov 2014, Radosavljević 2007, Sikimić 2005). The last 50 years saw the emergence of what could be termed "Bayash diaspora": as part of wider labour migration waves from the Balkans, starting with 1960s, the Bayash have been settling elsewhere on the European continent. The Rudari from Bulgaria (the name used to refer to the Bayash groups in this country), for example, mainly chose the Mediterranean countries (Slavkova 2017), while the Bayash from Yugoslavia, and later Serbia, preferred the German-speaking states.

Probably the first study about the latter ones is a 2008 linguistic paper which documents a "Romanian extra-territorial variety showing extensive RomanianSerbian code-mixing phenomena" spoken in Berlin, based on recordings of Bayash from Central Serbia settled in Germany (Leschber 2008: 247). The in-group variety of the speakers, which presented heavy code-mixing and code-switching between the three languages (Romanian, Serbian, German), was, according to the author, a "temporarily used variety, heavily endangered by obsolescence and language death" (idem: 259).

However, only recently has the Daj Nostri community specifically come to the forefront of research, being the focus of an MA thesis in social sciences 
(Brändle 2018). Daj Nostri ("our people") is a term used for self-appellation by the Bayash of Central and Eastern Serbia, which has only lately started being used in the scientific literature (Sorescu-Marinković, Kahl and Sikimić 2021: 11). Settled mainly in Germany, Austria and Switzerland, starting with the 1960s, as part of the gastarbeiter agreement which supplied workers to the Germanspeaking countries, they form today a tight-knit Bayash diaspora, fostering strong connections with the original community in Serbia.

\section{The Daj Nostri Facebook group}

With the emergence of the participatory Web era, in the mid-2000, and the advent of social networks, the Internet has become an important outlet for minority languages (Cunliffe 2007, Honeycutt and Cunliffe 2010, etc.). The real potential of the Internet for minority languages, notices Cunliffe, "lies not in the replication of traditional media and the formation of passive communities of minority language media consumers, but in the formation of active communities of collaborative minority language producers" (2007: 136-137).

Daj Nostri (https://www.facebook.com/groups/101707331836/) is currently one of the largest Facebook groups of the Serbian Bayash diaspora in Germany, Austria and Switzerland. This closed group was launched in 2009, and at the moment (April 10, 2020) numbers 9,112 members who actively use their native variety, Bayash Romanian, for online communication. The main part of the content posted in the group consists of status updates, memes, videos, live parties etc., with an entertaining character. Using Bayash Romanian is never stated as a purpose (cf. Stern 2017), though the description of the group suggests that all members speak it and this is what brings them together. The parallel use of Serbian and German can be interpreted as a consequence of the actual state of the vernacular today, which probably has a reduced range of use, with the other two languages being preferred in modern communication and for the sake of accuracy (cf. SorescuMarinković and Huţanu 2019 for the online use of Vlach Romanian).

\section{Methodology}

As observation is the bottom line of any fieldwork, and online observation offers a certain degree of ethnographic grounding in the "virtual field", I have been doing systematic observation of the group since September 2018, when I became a member. Like in any ethnographic endeavor, this allowed me to acquire some of the "tacit knowledge" underlying the semiotic practices of regular members (Androutsopoulos 2013: 7).

However, as digital language data is strikingly heterogeneous and available in overwhelming amounts, sampling was necessary. ${ }^{1}$ First, I used random

1 See Herring's six criteria for data sampling: random, by theme, by time, by phenomenon, by individual or group, and by convenience (Herring 2007). 
sampling - 10 days in October, combined with sampling by time - two years in a row, 2018 (October 20-29) and 2019 (October 1-10). The longitudinal data collected at roughly the same time in two successive years was supposed to show the frequency with which Bayash Romanian was used, and the share of other languages in the communicational practices of Daj Nostri. As well, it was meant to register changes in the frequency which might have occurred during one year. Second, I used sampling by phenomenon, which focused on particular linguistic features or patterns of language use, combined with sampling by theme. Namely, using the search option offered by Facebook groups, I looked for several Bayash Romanian key-words, with different spelling, and thus selected openers in Bayash Romanian. On the basis of these openers I then analysed spelling and frequent topics talked about in this variety.

\section{Analysis}

\subsection{Frequency}

The online observation of the group and the comparative analysis of the posts during a ten-day period in 2018 and 2019 revealed that German was most frequently used, followed by Serbian, with Romanian coming in third. Namely, out of the 53 openers in October 2018, German was used to some extent in 32, Serbian, in 16, Romanian, in 7, English, in 4, while other languages (Spanish, Croatian, Macedonian) were used in 5 openers. The situation did not change much a year later, even if the number of wall events almost doubled. Thus, out of the 119 openers in October 2019, 65 were in German, 49 in Serbian, 20 in Romanian, 12 in English and 6 in other languages (Spanish, Croatian, French, Chinese).

Roughly speaking, about $15 \%$ of the total posts contained Romanian to some degree. However, it must be stressed that they comprised also the standard variety, Romania Romanian, apart from the Bayash variety, as part of the content was taken from Romanian sites, not created by the members.

\subsection{Plurilingual practices}

Using two or more languages at once, combining repertoires and code switching is the norm for Daj Nostri. Out of the all-time 26 posts containing Bayash Romanian that I selected with the use of most frequent Bayash Romanian key-words, 10 were monolingual (Bayash Romanian), 11 were bilingual: 10 used Bayash Romanian and German, one used Bayash Romanian, and Serbian; and 5 were trilingual, using Bayash Romanian, Serbian and German.

As a rule, the posts using only Bayash Romanian were very short:

Daj nostri sch totz skrije p njimzeschtsche...

(Daj nostri, and all are writing in German...)

Maj bunezua narod ....

(Good day, people...) 
However, there were also notable exceptions, like the one below:

maj bun djimnjaca koritarilor.eece bijau kafe, mam gendjit deshe noj nu skrijem kumvorbim? noj trebe se njenvicem se skrijem pe ljimba nostre.vorbim ciginjeshte a ckrijem njemceste. deshe? normal ac trebuji toc daj nostri se invece orginal se ckrije se se vorbaske rominesce.ke asha nikad nu al se merzem la ince. al se ruminjem tot in lok.

(Good morning, through carvers. I'm drinking coffee. I thought about why we do not write the way we speak. We must learn to write in our language. We speak Gypsy, but write German. Why? Normally, all Daj Nostri should learn originally to write and speak Romanian. Like this, we will never move forward, but will stay in one place.)

As for the bilingual posts, of which the Bayash Romanian-German combination was the most frequent, German was the dominant, matrix language, with embedded Bayash Romanian words (cf. Leschber 2008). In the trilingual posts I analysed, Bayash Romanian was the matrix variety, with embeddings from Serbian and German:

Hallo dobar Dan amfrut se intreb Kare schtije u Geschäft bun se fak sche jo uzire bajn aschu tez sche mije $\underline{\text { hvala }}^{2}$

(Hello, good afternoon. I wanted to ask who knows of a good business to make a bit of money. Help me. Thank you.)

\subsection{Spelling}

The Daj Nostri competence in several languages means that more orthographies are available to them. Given that Bayash Romanian is only the medium of family communication and Daj Nostri have never attended school in Romanian, they write it down with the help of the two languages they can write in: Serbian and German. The orthography is diverse, but predictable, and created on the spot by the members of the group, generally following the conventions of the Serbian or German language, but also using Romanian or other special characters, to convey in writing sounds specific to their vernacular.

Below is an example of Bayash Romanian written with German and Serbian spelling:

Jo wrou se spasesk pumintu sta... Mije num trebuje om kare sische se Fak turte de prombj

(I want to save the world... I don't need a man who can make corn cakes.)

In the following example, Bayash Romanian is spelled according to the orthographic rules of Serbian, with the Romanian letter $\hat{a}$ rendering both /ə/ and /i/:

Aša sâ sâše samo la rumunj. La noi sâ sâše "bja un joint bzw. Câgarâ.

$\mathrm{Nu}$ jesć rumunâ, Oder

(Only Romanians talk like that. We say to drink a joint, respectively a cigarette. You are not Romanian, or...)

2 German, Bayash Romanian, Serbian. 


\subsection{Instances of use}

Several topics were talked about almost exclusively in Bayash Romanian, namely traditional culture, family and community relations, language of the community and free time. Out of the relevant 26 all-time posts selected, five were connected to buying the bride (the used key-words were banj da fata "money for the girl" and banj "money"), a topic which raised heated debates:

NARODULOR eine frag bei daj nostri was denkt ihr über die sache dali s mai se ja BANJ PE VETCE. ????? und auf die ganze geschichtte. schon damit bekant???

(People, a question for Daj Nostri. What do you think, are girls still bought? And about the whole story. Sounds familiar?)

The second most frequent topic, family ties within the community, where everybody is distantly connected to everybody, also engaged many members of the group, in an attempt to find whether Daj Nostri living abroad have initially been part of the same family or clan in native Serbia. The search for this sampling was done with the help of the patronymic particle alu ("of"), which is part of the traditional name by which the Bayash are known within the community:

eine frage an euch: ,, mich würde es Interessieren wo her ihr alle kommt und alu kure santcec, kann ja sein das man übere ein paar ecken verwant ist da wir ja alle irgendwie hier ,daj nostri sind

(A question for you: I would be interested where you all come from and whose you are. It can be that we are all related, only a few corners apart, because all are here somehow Daj Nostri.)

The post above, from April 18, 2012, triggered a record number of 95 comments. Here are only a few of them:

Jo sind Bäd alu Nesa, alu Voja Gjaku ;-)

(I am Bäd of Neša of Voja Gjaku.)

jo sint bajtu alu Raja alu Nizu al shonti und meine muma ist aus Jovanovic

(I am the son of Raja of Nizu of Shonta and my mom is of Jovanović.)

Jo sind fata Alu Draga nipota alu baliku din Filipovic naupara

(I am the daughter of Draga, granddaughter of Balik from Filipović, Naupara.)

\section{Discussion and conclusions}

Created and accessed by Bayash who call themselves Daj Nostri, originate in Central and Eastern Serbia, and live in the German-speaking countries, the Daj Nostri Facebook group shapes a community which uses the language resources creatively and plays an important role in defining a Bayash diaspora identity. Even though the member-created content in Bayash Romanian is not sizable, its mere existence is remarkable, as there is no tradition of using this variety in writing. 
Daj Nostri have extended repertoires and competence in several languages, which they freely and creatively use to communicate. The non-standard spellings and frequent codeswitching signal that the attitude of the members towards mixing language resources at their disposal is relaxed. The informality of the medium (Facebook) also makes people feel freer to write the language in any way that does not impede communication.

The use of a minority language in electronic media is often interpreted as a contestation of "ideologies of contempt" (Dorian 1998). Accordingly, the online presence of a minority language may provide "a way to challenge perceptions of particular minority languages as being old-fashioned, rural or of low social status" (Cunliffe 2007: 134). Thus, despite the fact that Bayash Romanian has always been associated with tradition, old age and village life, being used now on Facebook, it becomes cool, modern and visible, aligned less with the past, and more with urban sophistication. Even though the use of the vernacular on the Internet will not necessarily increase the number of speakers, it may result in an ideological transformation which could empower and encourage young speakers to use it more often offline, and not be ashamed.

\section{References:}

Androutsopoulos, Jannis (2013). Online data collection, in: Data collection in sociolinguistics. Methods and applications [eds. Christine Mallinson, Becky Childs, Gerhard Van Herk], Routledge, pp. 236-249.

Brändle, Mario (2018). Daj Nostri in Vorarlberg. Eine sich wandelnde Community im Fokus der Sozialen Arbeit. MA thesis in Social Sciences, Fachhochschule Vorarlberg, University of Applied Sciences, Masterstudiengang Interkulturelle Soziale Arbeit (manuscript).

Cunliffe, Daniel (2007). Minority Languages and the Internet: New Threats, New Opportunities, in: Minority Language Media: Concepts, Critiques and Case Studies [eds. Mike Cormack, Niamh Hourigan], Multilingual Matters, pp. 133-150.

Dorian, Nancy (1998). Western language ideologies and small-language prospects, in: Endangered Languages: Language Loss and Community Response [eds. Lenore A. Grenoble, Lindsay J. Whaley], Cambridge University Press, pp. 3-21.

Herring, Susan (2007). A faceted classification scheme for computer-mediated discourse, in: Language@Internet, 4 <http://www.languageatinternet.org/ articles/2007/> (3/10/2019).

Honeycutt, Courtenay and Daniel Cunliffe (2010). The use of the Welsh language on Facebook. An initial investigation, in: Information, Communication E Society, 13/2, pp. 226-248.

Leschber, Corinna (2008). Romanian-Serbian code-mixing phenomena, in: The Romance Balkans [eds. Biljana Sikimić, Tijana Ašić), Belgrade: Institute for Balkan Studies, pp. 247-260. 
Marushiakova, Elena and Vesselin Popov (2014). Romanian speaking 'Gypsy' communities in Eastern Europe, in: Romii/tiganii din Republica Moldova: Comunitate etnosocială, multiculturală, istorico-tradițională (1414-2014) [ed. Ion Duminică], Chişinău: Academia de Ştiințe a Moldovei, pp. 15-24.

Radosavljević, Petar (2007). Romi Bajaši u Hrvatskoj - govornici rumunjskog dijalekta, in: Jezik i identiteti [ed. Jagoda Granić], Zagreb - Split: HDPL, pp. 505-515.

Sikimić, Biljana [ed.] (2005). Banjaši na Balkanu. Identitet etničke zajednice, Beograd: Balkanološki institut.

Slavkova, Magdalena (2017). Social Ties of Bulgarians and Rudari in the Mediterranean Countries, in: Balkan and Balticum: Current Studies in the Postsocialist Space [eds. Ekaterina Anastasova, Mare Kõiva], Tartu: EKM Teaduskirjastus, pp. 42-69.

Sorescu-Marinković, Annemarie and Monica Huțanu (2019). Ideology and representation of Vlach Romanian online. Between linguistic activism and unengaged language use, in: Bulletin of the Transilvania University of Braşov. Series IV. Philology and Cultural Studies 12(61)/1, pp. 71-86.

Sorescu-Marinković, Annemarie, Kahl, Thede and Biljana Sikimić (2021). Boyash Studies: Towards a New Paradigm. Editors' Introduction, in: Boyash Studies: Researching "Our People" [eds. Annemarie Sorescu-Marinković, Thede Kahl, Biljana Sikimić], Berlin: Frank\&Timme, pp. 9-36.

Stern, Alissa Joy (2017). How Facebook can revitalize local languages: lessons from Bali, in: Journal of Multilingual and Multicultural Development 38:9, pp. 788-796.

\section{Manjinski jezici u digitalnom dobu. Daj Nostri i bajaški rumunjski na društvenim mrežama}

Bajaši su etnička skupina koja govori rumunjski jezik, raširena je po cijelom Balkanu, a većinsko stanovništvo ih uglavnom smatra Romima. Ovaj se rad bavi bajaškom skupinom Daj Nostri (,naši“), koju čine Bajaši iseljeni iz centralne i istočne Srbije u Austriju, Njemačku i Švicarsku, a koji su nedavno započeli koristiti svoj bajaški varijetet za online komunikaciju. Fokus rada je na Facebook grupi Daj Nostri, koja okuplja više od 9.000 članova, i na načinu na koji oni koriste bajaški rumunjski (slučajevi upotrebe, učestalost, pravopis, višejezične prakse itd.). Unatoč činjenici da je ovaj jezični varijetet uvijek bio povezan s tradicijom i seoskim životom, on sada, korištenjem na Facebooku, postaje svjež, moderan i vidljiv. Iako njegova upotreba na Internetu neće nužno povećati broj govornika, ona može rezultirati ideološkom transformacijom koja bi mogla ojačati i potaknuti mlade govornike da ga više koriste i izvan Interneta.

Ključne riječi: Bajaši, rumunjski, Facebook, manjinski jezici, online komunikacija 
